\title{
Peripartum cardiomyopathy in a patient with hyperprolactinaemia
}

\author{
G. S. MATHARU* \\ M.B., M.R.C.P.
}

\author{
M. H. OELBAUM
}

M.D., F.R.C.P.

North Manchester General Hospital, Crumpsall, Manchester M8 6RL

\begin{abstract}
Summary
The clinical course of a patient with peripartum cardiomyopathy and hyperprolactinaemia is described. Hyperprolactinaemia may be a factor in this patient's heart failure.
\end{abstract}

KEY WORDS: peripartum cardiomyopathy, hyperprolactinaemia, amenorrhoea, galactorrhoea.

\section{Introduction}

Peripartum cardiomyopathy is a rare heart muscle disorder of unknown aetiology which presents with heart failure in the last month of pregnancy or within the first 5 months (Demakis and Rahimtoola, 1971). It appears to occur more frequently in older, multiparous women and with twin pregnancies and toxaemia (Demakis et al., 1971). This disorder tends to recur in subsequent pregnancies, sometimes with complete remission of symptoms in the intervening period. Some patients however go on to have repeated episodes of heart failure unrelated to pregnancy (Demakis et al., 1971; Stuart, 1968).

Curtarelli and Ferrari (1979) reported a case of congestive heart failure and cardiomegaly in a patient with a prolactin secreting pituitary tumour and speculate whether this is a coincidence or not. We report a patient with peripartum cardiomyopathy and hyperprolactinaemia who has been followed up for more than 13 years.

\section{Case report}

Four months after giving birth to a normal female infant, a 29-year-old white woman presented in September 1969 with a 2-week history of exertional and paroxysmal nocturnal dyspnoea, nausea and a right hypochondrial discomfort. She was a nonsmoker and only took alcohol occasionally. Her only pregnancy and puerperium had been uncomplicated and there was no previous history to suggest a cardiac

\footnotetext{
*Present address: Queen Mary's Hospital, Sidcup, Kent DA14 6LT.
}

disorder. Menarche occured at the age of 13 years and thereafter she had normal monthly periods. On examination the patient was tachypnoeic and orthopnoeic. The pulse rate was 120 per min, regular and the blood pressure (BP) was $100 / 60 \mathrm{mmHg}$. There was no peripheral oedema and jugular venous pressure was not raised. The apex beat was not displaced and no murmurs were present. There were signs of a moderate right pleural effusion. The liver was enlarged $5 \mathrm{~cm}$ below the costal margin and tender. Investigations: the chest radiograph showed moderate cardiomegaly and confirmed a right pleural effusion. The electrocardiogram (ECG) showed sinus tachycardia, bifid $\mathbf{P}$ waves, $T$ wave flattening in leads I, aVL, V5, V6. Complement fixation tests on a single blood sample did not show raised titres to influenza $A$ \& B virus, adenovirus, $\mathrm{Q}$ Fever and Mycoplasma pneumoniae. The patient was treated with digoxin and frusemide and made a rapid recovery. Radiologically, her heart returned to normal size within 3 months. All medication was discontinued 11 months later.

Subsequently she remained well apart from the galactorrhoea and amenorrhoea which persisted following the pregnancy. A pelvic examination under anaesthetic was normal. In February 1973 the patient presented with fatigue, breathlessness and haemoptysis of 1-week duration. Her pulse was 120 per min, regular but low in volume. The jugular venous pressure was raised at $10 \mathrm{~cm}$ and the BP was $90 / 60$ $\mathrm{mmHg}$. A soft apical systolic murmur was heard. The lung fields were clear. The chest radiograph showed moderate cardiomegaly with normal lung fields. The ECG did not differ from that in September 1969. The patient made a good recovery with digoxin and diuretics.

In April 1976 the patient was readmitted to hospital for investigation of amenorrhoea and galactorrhoea. Examination confirmed engorged breasts with galactorrhoea on gentle palpation. There were no clinical features to suggest hypopituitarism, acromegaly or a thyroid disorder. The heart was not enlarged and the BP was $130 / 90 \mathrm{mmHg}$. The visual 
fields were normal on confrontation and there was no papilloedema. Serum T3, T4 and thyroid stimulating hormone, diurnal cortisols, were normal. Basal fasting serum prolactin was $>125 \mathrm{ng} / \mathrm{ml}$ (normal $<18$ $\mathrm{ng} / \mathrm{ml}, 1 \mathrm{ng} / \mathrm{ml}=20 \mathrm{mu} / \mathrm{l})$. Three further blood samples on the same morning showed serum prolactin $>125 \mathrm{ng} / \mathrm{ml}$. Insulin tolerance test, thyrotrophin releasing hormone test, serum growth hormone, skull radiographs and a computed tomograph (CT) brain scan were all normal. The chest radiograph showed the cardiac transverse ratio (CTR) just within the upper limit of normal. The serum prolactin in July 1980 was $>1600 \mathrm{mu} / 1$ (normal $<350 \mathrm{mu} / 1$ ).

In April 1981 the patient gradually became more breathless on exertion and she was having occasional paroxysms of supraventricular tachycardia which responded to oxprenolol $20 \mathrm{mg}$ tds. The chest radiograph showed return of cardiomegaly (Fig. 1). Her dyspnoea settled over the next few weeks. The echocardiograms showed minimal enlargement of the left atrium, a dilated left ventricle but no valvular disease. Antibodies to cytomegalovirus, Toxoplasma gondi and Coxsackie B 1-5 were not raised. The patient remains asymptomatic with a BP of $90 / 60$ $\mathrm{mmHg}$ and a soft apical systolic murmur. Radiologically, her heart size remains at the upper limit of normal. She continues to have amenorrhoea and galactorrhoea.

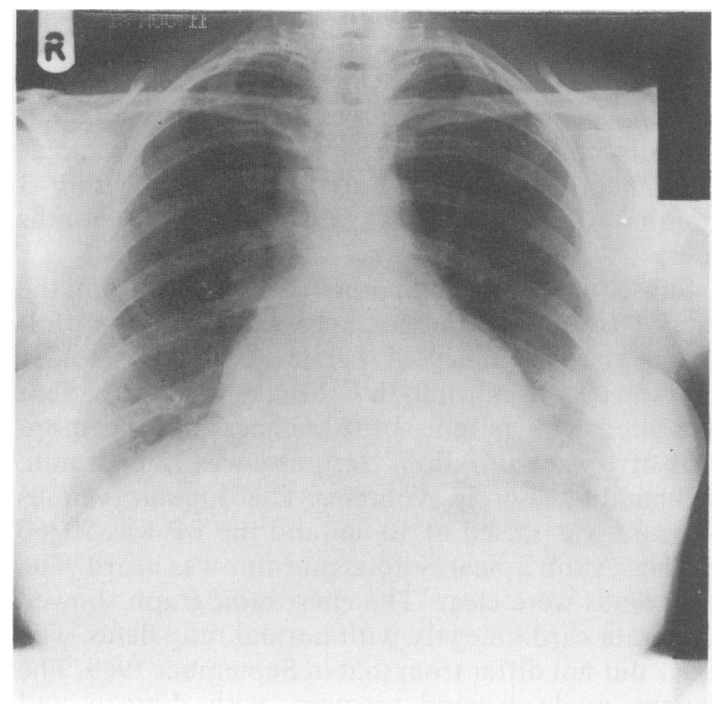

FIG. 1. PA Chest radiograph of patient in July 1981. Cardiac transverse ratio (CTR) $16 \mathrm{~cm} / 28 \mathrm{~cm}$.

\section{Discussion}

This patient has had amenorrhoea and galactorrhoea following the pregnancy more than 13 years ago. Although her blood was not assayed fo prolactin until 1976, it is highly likely that hyperpro $\frac{}{3}$ lactinaemia has been present since the pregnancy ind view of the persistent amenorrhoea and galactore rhoea. The patient has remained euthyroid and he only medication had been digoxin and diuretics and? lately oxprenolol. Apart from the hyperprolactinae은 mia, tests for anterior pituitary function are ale normal. Her skull X-rays have remained normal andf a recent CT brain scan has not shown a pituitarya tumour. A pituitary microadenoma is the most likelyes cause of her hyperprolactinaemia.

The patient presented with heart failure 4 months following childbirth. Her heart failure responde promptly to digoxin and diuretics. There were two recurrences of heart failure, the first occurring im 1973 and accompanied by probable pulmonary. infarction and the second in 1981. In the absence of any obvious cause of the heart failure, the aboves features together with the echocardiographic datae strongly favour a diagnosis of peripartum cardiomyo $\vec{\imath}$ pathy. A viral myocarditis is still a possibilityo especially as Melvin et al. (1982) were able to diagnose myocarditis only as a result of transvenous endomyocardial biopsy in three patients with peris

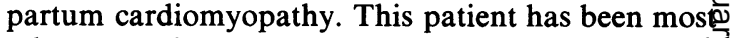
reluctant to have any invasive investigations.

The coexistence of a cardiomyopathy and hypêr $\vec{\infty}$ prolactinaemia in this woman may still be a coinsit + dence despite a previous report of cardiomyopathyging a patient with a prolactin secreting pituitary tumours (Curtarelli and Ferrari, 1979). However, a number of observations suggest a possible role of prolactin ing the pathogenesis of heart disease. Cardiomegaly and heart failure in the absence of ischaemic heart disease, hypertension, diabetes or thyroid disorder is? a recognized feature of acromegaly (Pepine and Aloia, 1970; Joplin, Doyle and Lewis, 1973). Growth hormone and prolactin have many chemical and biological similarities and hyperprolactinaemia may be found in up to $32 \%$ of patients with acromegalyo (de Pablo et al., 1981). In some acromegalic patients serum prolactin does not fall with growth hormone after pituitary surgery (Franks, Jacobs and Nabarro 1976). In a prospective study of heart disease ino acromegaly, McGuffin et al. (1974) were unable to show a clear relationship between cardiac disease ando plasma growth hormone levels. It is therefore possible that acromegalic heart disease is due to someo pituitary product other than growth hormone and N this product may be prolactin. Hanssen and Torjesen N (1977) and Nicoll (1974) suggest that prolactino participates in sodium retention and osmoregulation

This patient appears to have a peripartum cardio- $\frac{-}{D}$ myopathy and longstanding hyperprolactinaemia. The latter may be a factor in her heart failure as 0 recently suggested by Curtarelli and Ferrari (1979). 
Our documentation of a second case of cardiomyopathy with hyperprolactinaemia prompts us to suggest that hyperprolactinaemia should be looked for in women of childbearing age with unexplained cardiomyopathy.

\section{Acknowledgment}

We thank Dr B. Livesley for his helpful comments.

\section{References}

Curtarelli, G. \& Ferrari, C. (1979) Cardiomegaly and heart failure in a patient with prolactin secreting pituitary tumour. Thorax, 34, 328.

Demakis, J.G. \& Rahimtoola, S.H. (1971) Peripartum cardiomyopathy. Circulation, 44, 964.

Demakis, J.G., Rahimtoola, S.H., Sutton, G.C., Robert MeaDows, W., Szanto, P.B., Tobin, J.R. \& GUnNaR, R.M. (1971) Natural course of peripartum cardiomyopathy. Circulation, 44, 1053.

Franks, S., Jacobs, H.S. \& Nabarro, J.D.N. (1976) Prolactin concentrations in patients with acromegaly: clinical significance and response to surgery. Clinical Endocrinology, 5, 63.
HANSSEN, K.F. \& TORJESEN, P.A. (1977) Increased serum prolactin in diabetic ketoacidosis; correlation between serum sodium and serum prolactin concentration. Acta Endocrinologica, 85, 372.

JoPliN, G.F., DoYLE, F.H. \& LEWIS, P.D. (1973) A case of acromegalic heart disease. British Medical Journal, 1, 718.

MCGuffin, W.L., Sherman, B.M., Roth, J., Gorden, P., Kahn, C.R., ROBERTS, W.C. \& Frommer, P.L. (1974) Acromegaly and cardiovascular disorders. A prospective study. Annals of Internal Medicine, 81, 11.

Melvin, K.R., Richardson, P.J., Olsen, E.G.J., Daly, K. \& JACKSON, G. (1982) Peripartum cardiomyopathy due to myocarditis. New England Journal of Medicine, 307, 731.

NiCOLL, C.S. (1974) Physiological actions of prolactin. In: Handbook of Physiology. Section 7 Endocrinology Vol. 4 (Eds. E. Knobil and W. H. Sawyer) part 2, p. 253. Williams and Wilkins, Washington.

Pablo, F. De, Eastman, R.C., Roth, J. \& Gorden, P. (1981) Plasma prolactin in acromegaly before and after treatment. Journal of Clinical Endocrinology and Metabolism, 53, 344.

Pepine, C.J. \& AloiA, J. (1970) Heart muscle disease in acromegaly. American Journal of Medicine, 48, 530.

STUART, K.L. (1968) Cardiomyopathy of pregnancy and puerperium. Quarterly Journal of Medicine, 37, 463.

(Accepted 31 March 1983) 